\title{
Van askop, lantaarns en wieken: molenterminologie in de Zuid-Nederlandse dialecten
}

\author{
Veronique De Tier
}

\section{Inleiding}

Over molens is al veel geschreven. Ook in de taalkunde is de molen al vaak het onderwerp geweest van allerlei studies. Zelf maakte ik in 1985 een licentiaatsverhandeling over de molenaarsterminologie in Oost-Vlaanderen. Ook in ZeeuwsVlaanderen kwam er in die periode een woordstudie over molenaarstermen. De drie regionale woordenboeken van de Vlaamse, Brabantse en Limburgse dialecten hebben elk een aflevering over de molenaar en Jan Stroop schreef in 1977 een proefschrift over de molentermen in de Nederlandse dialecten. In dit artikel leg ik kort uit hoe een (wind)molen werkt, maar ik belicht daarbij vooral de woordenschat in de Zuid-Nederlandse dialecten en heel specifiek enkele belangrijke onderdelen die taalkundig interessant zijn. Dit artikel maakt vooral gebruik van de drie regionale woordenboeken en het proefschrift van Jan Stroop die hierboven en in de bibliografie vermeld worden. (1)

\section{Soorten molens}

Er bestaan verschillende types molens waarvan er in Vlaanderen twee frequent voorkomen: de windmolen en de watermolen. In wat hierna volgt komt vooral de windmolen aan bod, maar omdat sommige molenonderdelen voor beide types identiek zijn, zal ook hier en daar de watermolen genoemd worden. Het verschil tussen beide molens is uiteraard de aandrijving. In het ene geval worden de maalstenen in beweging gebracht door de wind, in het andere geval door de kracht van het water. Onderdelen die in beide types aanwezig zijn, zijn uiteraard de maalstenen die aangedreven worden via allerlei spillen en tandwielen.

In Vlaanderen komen in hoofdzaak twee verschillende types 


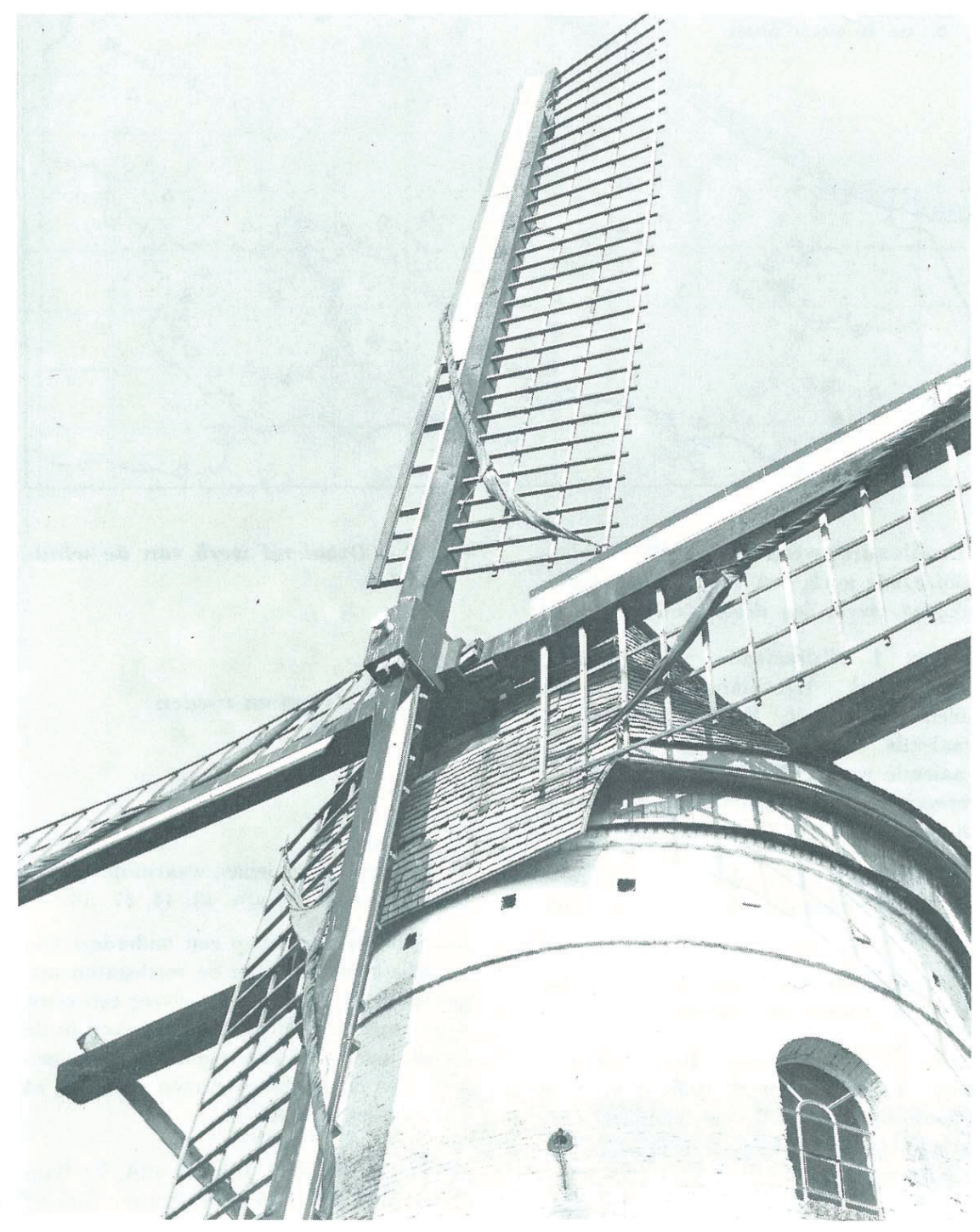

Askop en wieken van de Fauconniersmolen te Oordegem (Lede) 
windmolen voor: de houten molen en de stenen molen. De houten molen wordt ook standaardmolen of staakmolen genoemd, naar het belangrijkste onderdeel binnenin, de standaard, waaromheen de volledige houten molen kan draaien. De stenen molen heet meestal stenen molen, maar als de molen bijvoorbeeld een gaanderij heeft, heet hij stellingmolen, galerijmolen of gaanderijmolen. Houten molens komen vooral in het zuiden voor, stenen of Hollandse molens vooral in Nederland.

Het binnenwerk van beide types komt in grote lijnen overeen. De werking lijkt ingewikkeld, maar is relatief eenvoudig. De roeden of wieken draaien door de kracht van de wind en zetten daardoor een horizontale molenas in beweging. Daarop zit een kamwiel, dat een ander wiel (de lantaarn of het rondsel) in beweging zet, dat de kracht overbrengt op een spil die door middel van een ijzeren stuk in de stenen de maalstenen doet draaien. Bovenop de maalstenen staat een graanbak waarin de molenaar het graan giet. Het gemalen graan komt aan de onderkant van de stenen terecht in de zakken, die dan via een systeem van touwen, het luiwerk, verplaatst kunnen worden, naar beneden gelaten of naar boven getrokken. De molen heeft uiteraard ook een remsysteem, de vang en een systeem om de stenen verder en dichter bij elkaar te brengen om fijner of minder fijn te malen, de licht.

De watermolen werkt volgens ongeveer dezelfde principes. Het water brengt een wiel in beweging dat een spil onder de maalstenen in beweging zet via allerlei wielen of raderen en spillen. Ook daar heb je een licht, een graanbak, enz.

De molenaar heet in het Vlaamse gebied meulenaar (in WestVlaanderen) of mulder (in Oost-Vlaanderen). Het type maalder komt voor in de Denderstreek. Mulder en maalder komen verder oostwaarts nog terug: in Limburg wordt dat dan moller/molder of muller/mulder.

\section{De windzijde van de houten molen}

De standaardmolen heeft een vierkante romp met vier zijden. Vooral de zijde waar de roeden zitten, krijgt verschillende namen in ons taalgebied. In tegenstelling tot wat leken meestal denken, is dit niet de voorkant van de molen, maar de achterkant. Dat wordt ook weerspiegeld in de naamgeving. We merken hier 
wel dialectverlies, zelfs bij de molenaars, want zowel voor- als achterkant komen voor in het door ons verzamelde materiaal.

De meeste namen voor de windzijde verwijzen naar de wind, en dat zien we in de samenstellingen met storm, weer en wind als eerste element (zie kaart 1, windzijde (Stroop)). Weer, dat in het uiterste oosten voorkomt, zou vroeger onder andere 'storm' betekend hebben. Het wordt in deze samenstelling dus specifieker gebruikt dan wat wij nu onder het weer verstaan.

Het tweede element in deze samenstellingen is o.a. kant en muur, maar ook weeg en eind(e). Windweeg is vooral in het westen te horen, stormeind is een oostelijke benaming. Weeg kennen we ook in de landbouwersterminologie in bijvoorbeeld poeiweeg. Weeg is in het westen een algemene aanduiding voor een gevel of wand van planken, vlechtwerk of klei. Ook einde betekent wand of zijde, denk bijvoorbeeld aan een hoofdeinde van een bed, of

3. WINDZIJDE (breast of the postmill) na 1900

$O$ windweeg

tot 1900

windkant

- windweeg, -einde

(๑) windzijde

$\odot$ wind-

$\square$ stormeinde, storm \stormeind, -weeg

自 stormkant

$\checkmark$ weerkant, -zijde $\quad$ weerkant

borst, -eind, -kant

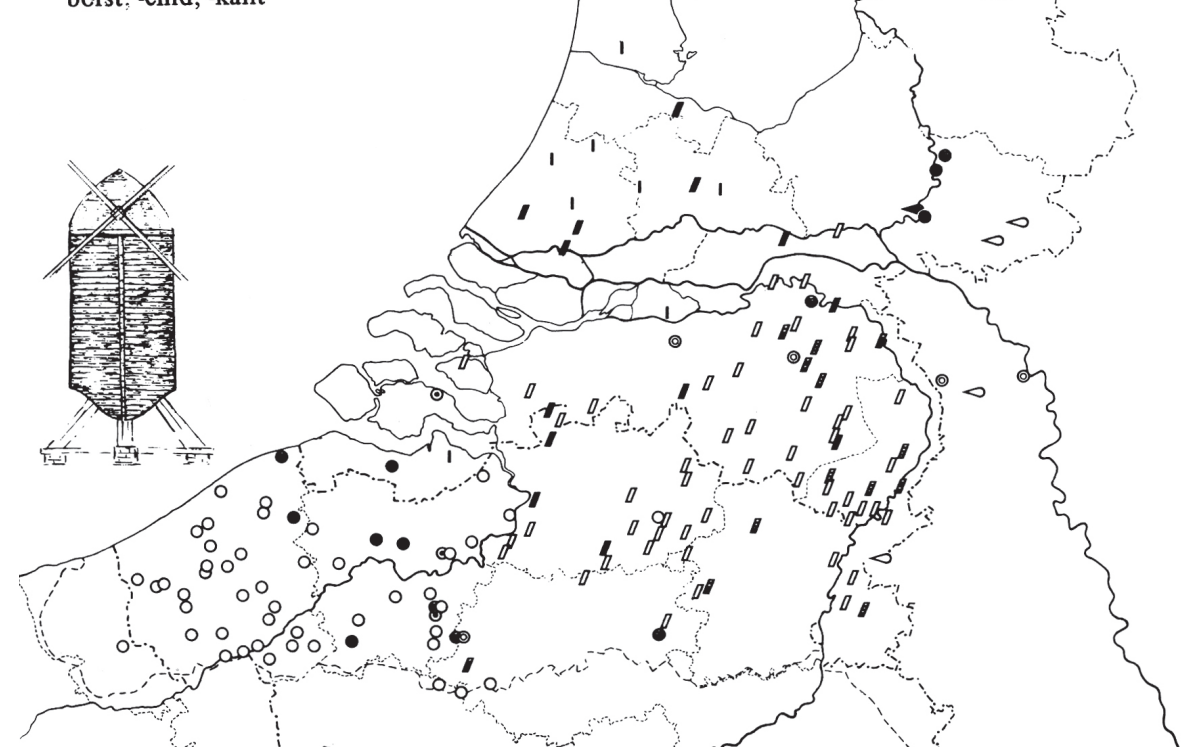

Kaart 1: de windzijde van de molen (Stroop : 39) 
het vooreinde van een akker. Eind komt ook voor in keuvelens, of keuveleinde, een term die ook in de molenterminologie in gebruik is voor een zijde van een kap (meestal van een stenen molen). Dezelfde elementen komen voor in de benamingen voor de windluiken, die aan weerskanten van de askop (het deel van de as dat buiten de molen komt) zitten en die nodig zijn om de askop en de roeden te bereiken voor inspectie en onderhoud (zie kaart 2). Wind, storm en weer worden gecombineerd met luiken, deuren of vensters, namen die verwijzen naar de manier van afsluiten van de gaten. Een nieuw element is water, dat verwijst naar de regen, en dus ook naar weersomstandigheden. Het weer is immers een belangrijk element in het werk van een molenaar. De luiken dienen onder andere om de regen buiten te houden. Kapluiken en spruitluiken horen bij de stenen molen. Deze namen verwijzen naar de plaats van de luiken in de molen, nl. in de kap van de molen, waar ook de spruiten, de schoren die aan een kap van een stenen molen zijn bevestigd, zich bevinden. Luik, venster en deur verwijzen weer naar de manier waarop deze gaten afgesloten kunnen worden.

Een wat aparte benaming is ravensblinden. Blinden zijn eveneens afsluitingen, maar het eerste element betekent 'dakspar', waardoor het geheel dus verwijst naar een luik tussen de daksparren. Net zoals de vorige twee benamingen, verwijst het woord dus naar de plaats van de luiken in de kap.

Om nog even bij wind en storm te blijven, bespreken we aan deze kant van de molen (aan de roeden) ook de windborden (zie kaart 3). De windborden dienen om de windvang te vergroten en kunnen wel of niet aangebracht worden aan de roeden, naar gelang van de windkracht. We hebben ook hier weer de wind-en storm-woorden maar nu gecombineerd met planken en borden (dat ook in de vorm berden voorkomt in het zuidoosten van Vlaanderen).

Benamingen die afwijken zijn steekbord en zwichtbord. Steekbord verwijst naar de handeling: je steekt de borden wel of niet op de roede. De benaming zwichtborden heeft dan weer te maken met het opleggen van zeilen en is oorspronkelijk een zeemansterm. Zwichten betekent 'zeilen of touwen weghalen', maar ook de windborden kunnen aangebracht en weggehaald worden. Die overdracht kon gemakkelijk gebeuren, omdat men net zoals in 
4. WINDLUIKEN (storm hatch) na 1900

$\theta$ windluiken $\diamond$ weerdeuren

$O$ winddeuren $A$ waterluiken

$\theta$ windvensters $\Delta$ waterdeuren

\& stormluiken watervensters

/ stormdeuren - (kap)luiken

$\checkmark$ stormblinden $\rightarrow$ spruitluiken

$\theta$ weerluiken $]$ ravensblinden

tot 1900

- windluiken

- winddeuren

$\Lambda$ waterdeuren

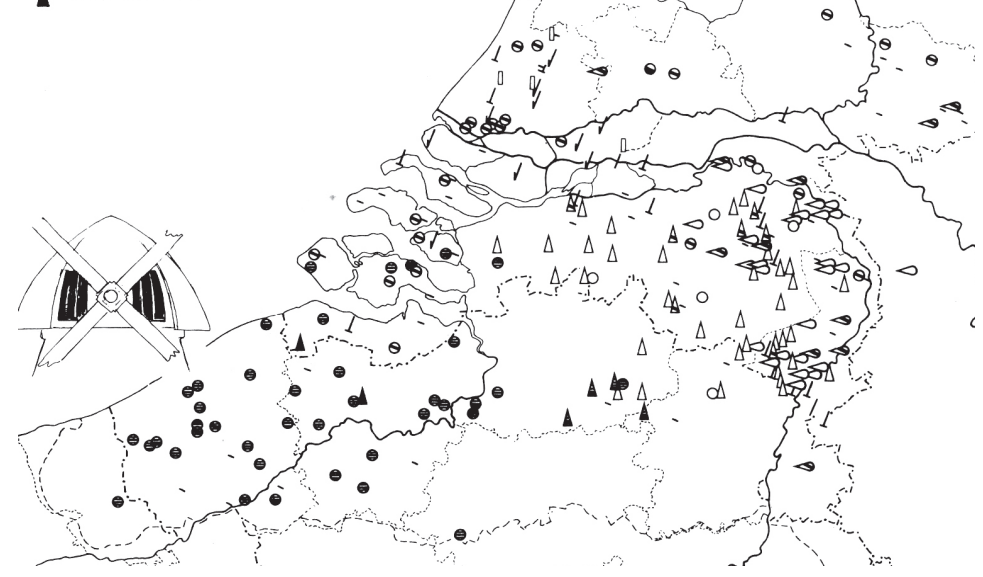

Kaart 2 : windluiken (Stroop : 45)

Kaart 3 : windborden (Stroop : 53)

5. WINDBORDEN (windboards)

na 1900

tot 1900

$\theta$ windborden

$O$ windplanken

$\&$ stormborden

/ stormplanken

- borden

- borden

I steekborden

awichtborden

windborden

166 
de scheepvaart zeilen gebruikt, die op de wieken gelegd worden. Dit zwichten kan dus gemakkelijk zijn overgegaan op de borden die ook al eens moesten weggehaald worden voor de wind.

\section{Roeden en hekwerk}

Roeden zijn balken met een enorme lengte, soms wel 25 meter lang. Als de roede uit één stuk bestaat, wat heel vroeger wel eens het geval was, kon die ook wel eens breken, vooral in het midden vlak bij de askop. Een ander veel gebruikt systeem was de roede niet uit één stuk te vervaardigen, maar een zware balk te gebruiken in het midden en die te verlengen met een balk aan weerskanten. Die verlengstukken worden lassen genoemd. Daaraan wordt het hekwerk dan bevestigd. Hekwerk en lassen samen worden ook wel einden genoemd. De middelste zware balk is de borst.

In ons taalgebied worden de roeden meestal roeden genoemd, behalve door leken die wieken gebruiken. Voor de kortere balken zijn vooral borst en pestel in gebruik, en in Frans-Vlaanderen buik (2). Borst wordt hier gebruikt in de betekenis van een onderdeel waarin sprake is van een verdikking of verbreding, omdat de molenborst ook het dikkere gedeelte van de roede vormt. Pestel is langs dezelfde metaforische weg molenterm geworden. Pestel is in zijn eerste betekenis de naam van een lichaamsdeel, waarschijnlijk een pees of spier in de arm. Ook in Engelse dialecten zou pestel 'been in ledematen' hebben betekend. De Bo herleidt het woord tot het Latijnse paxillus met de betekenis 'paaltje'. Ook buik is een lichaamsdeel met de ovedrachtelijke betekenis 'middenstuk, verbreed of dikker gedeelte'. (zie kaart 4)

De terminologie van de molenroeden is altijd ingewikkeld geweest. De leek spreekt van vier wieken, de molenaar van twee roeden, waaraan vier einden zijn bevestigd. Aan de borst of pestel zijn dus einden vastgemaakt, verlengstukken waaraan het hekwerk bevestigd wordt. De molenaars zelf geven voor het hekwerk hek of hekken of samenstellingen daarmee. Het hekwerk bestaat uit hekscheien en zomen. De hekscheien zijn de dwarse latten van het hekwerk, de zomen de lange dunne latten die evenwijdig lopen aan de roede. 
8. BORSTEN (stocks)

na 1900

$1650-1900$ tot 1650

/ borsten $\theta$ borst-

borst-

$<$ borstroeden

1 borststukken

- borstbomen, -balken

1 molenborsten

borsteinden

Ó pestels
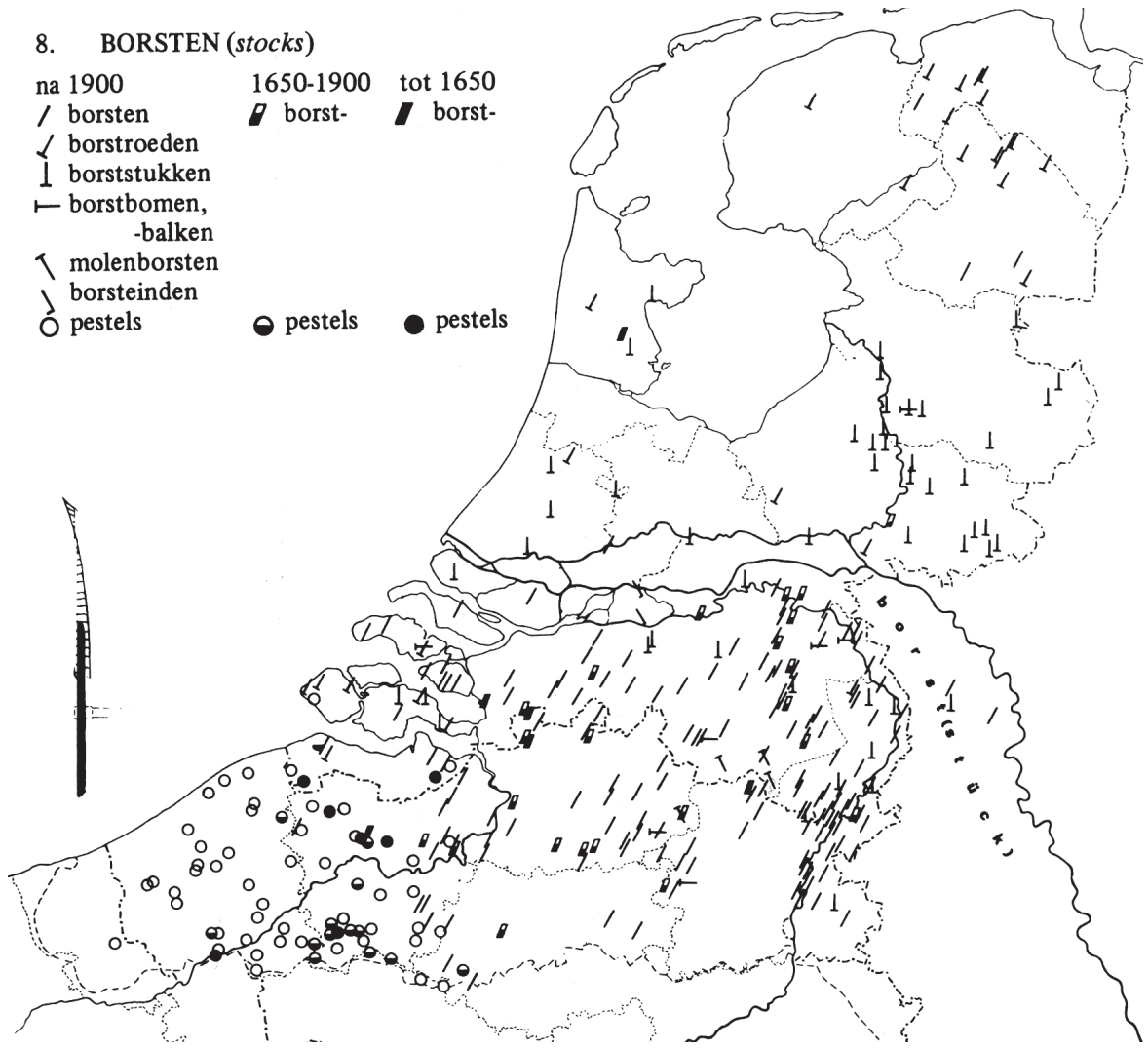

Kaart 4: de borsten van het hek (Stroop : 77)

Het woord schei of schee betekende in het Middelnederlands

168 o.a. spie, het is afgeleid van het werkwoord scheiden en het wordt gebruikt voor allerlei dwarslatten, en dus ook voor de dwarslatten van het hekwerk van een molen. Zomen en latten worden door elkaar gebruikt in het Vlaamse taalgebied. De naam zoom verwijst steeds naar een boord of rand. Wellicht werd zoom eerst gebruikt voor de laatste, buitenste lat, maar is het daarna ook de naam geworden voor de langse latten die er parallel mee lopen. Andere namen zijn stevels, lopers, lassen, enz.

Een wiek of hek staat nooit helemaal recht maar heeft een schuine stand. Dit wordt in het Nederlands de zeeg genoemd. Het woord zeeg is verwant met het werkwoord zijgen. Andere namen zijn schep, schoot, valling, steek, windschep, zak. Al deze woorden kunnen een kromming aanduiden, en dat geldt zeker niet alleen voor de molenterminologie. De woorden voor 
schuine stand van een hekwerk vinden we ook terug in de zeevissersterminologie voor bijvoorbeeld de romp van een schip (zie daarvoor de aflevering over zeevisserij van het Woordenboek van de Vlaamse Dialecten).

\section{Binnenwerk van de molen}

De twee roeden gaan door een askop (zie kaart 5 en afbeelding op $p$ 162). Hoofd dat vooral in het westen voorkomt is een oude benaming. Hoofd is vrijwel overal vervangen door kop, behalve in het uiterste westen. Dit is een voorbeeld van wat in de taalkunde Brabantse expansie wordt genoemd. Vanuit Brabant heeft het woord kop het oudere woord hoofd verdrongen. Maar in samenstellingen blijven de oudere benamingen dikwijls langer bewaard. De askop is het uiteinde van de molenas die horizontaal boven in de molen hangt en de beweging van de wieken overbrengt naar het binnenwerk. Deze as heeft uiteraard vooraan een speciale constructie. Je hebt de hals van de as, waarop lemmers liggen, een kraag, de as zelf, het pineind en de asbanden.

De hals van de as is het cilindervormig gedeelte dat met lemmers belegd is en op de halssteen rust en draait. De steen eronder draagt eigenlijk het volle gewicht van as en roeden. Omdat dit gedeelte van de as, de hals dus, door de versmalling uitermate onderhevig is aan slijtage, wordt die versterkt met smalle stroken ijzer waaromheen banden worden geslagen om het geheel bij elkaar te houden. De ijzeren stroken heten schenen of lemmers. Scheen verwijst weer naar het lichaam, en wordt overdrachtelijk gebruikt voor diverse lange smalle stukjes hout of ijzeren banden. De oorsprong van het woord lemmer ligt in het Latijnse lamna, lamina. Misschien heeft ook het verkleinwoord lamella invloed gehad. Lemmer is door dissimilatie, lemmet (dat we bijvoorbeeld kennen van een mes) door verwisseling van suffix uit lemmele ontstaan, een vorm die nog wel eens voorkwam in de $16^{\text {de }}$ eeuw. Hals is een metaforische benaming, en zoals we al eerder noteerden weer een overdrachtelijk gebruikte naam van een lichaamsdeel. De etymologie is duidelijk als we weten dat dit gedeelte tussen kop en lijf/romp te vinden is. In het Vlaamse 


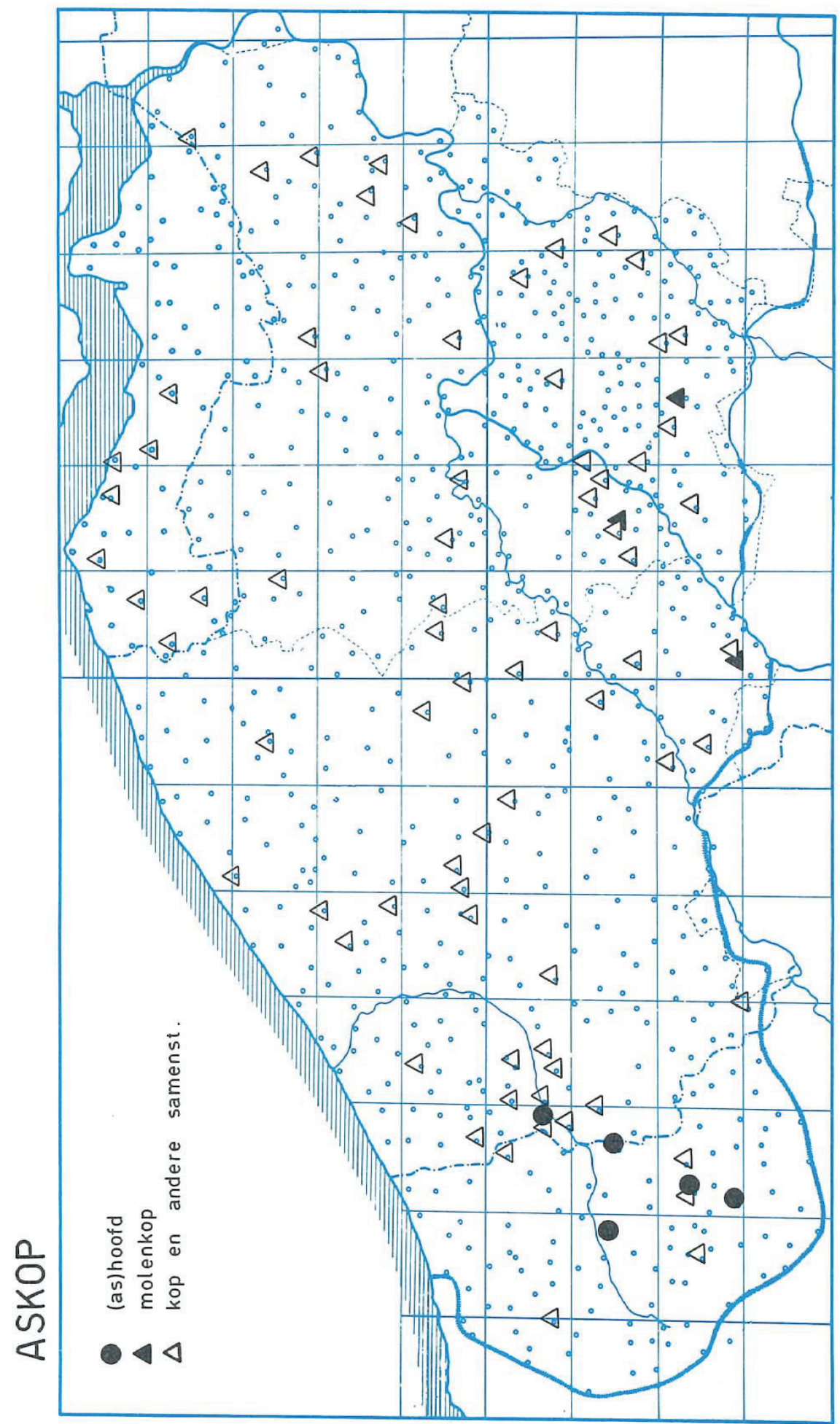

Kaart 5 : Askop (WVD) 
taalgebied komt ook de naam baan voor, dat etymologisch wat lastiger te verklaren is. Het is blijkbaar geen oude term, want Stroop heeft hem nergens aangetroffen voor 1900. Baan komt ook niet voor in een specifiek gebied, altijd wordt in de buurt ook wel hals genoemd. Een echte etymologische verklaring heeft Stroop niet gevonden. Volgens hem betekent baan hier 'glad oppervlak'

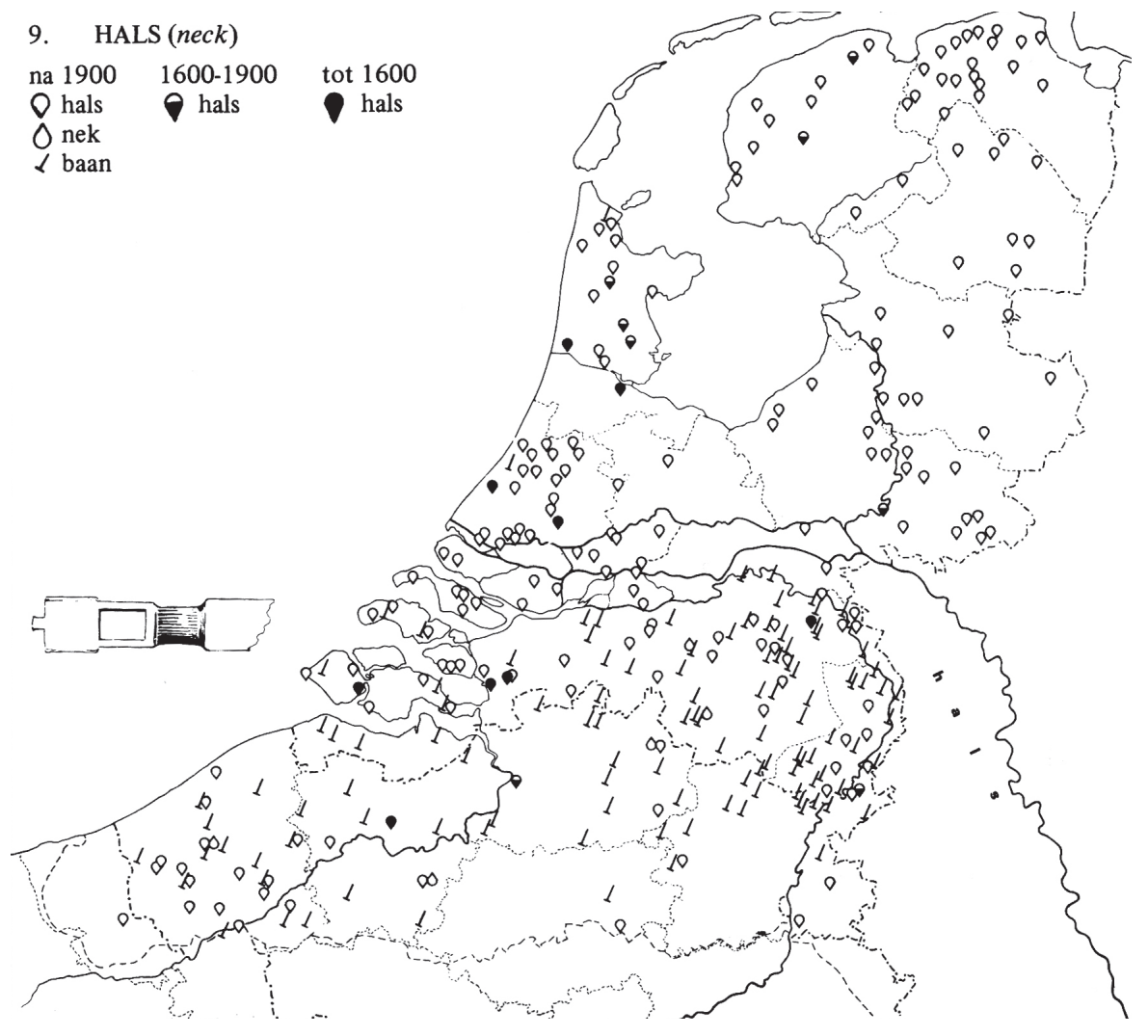

Kaart 6 hals (Stroop : 86)

omdat dit deel van de as immers glad en rond moet zijn (zie kaart 6).

Deze hals draait in een steen, die vooral halssteen en baansteen genoemd wordt. Er zijn ook enkele benamingen die verwijzen naar het materiaal van de steen (marmer of arduinsteen). Sommigen molenaars vergelijken de steen met een kussen (kussen/coussinet) waarop de hals rust. Hier is de functie dus van belang. Ook assteen drukt een soort functie uit, de steen ondersteunt de as. Dat geldt zeker voor baan- en halssteen die 
10. HALSSTEEN (neck bearing)

na 1900

$\checkmark$ halssteen

$\checkmark$ baansteen

4. marbel(steen)

[1 assteen

coussinet (en var.

kussen

$\triangleright$ kattensteen

tot 1600

halssteen

marbel(steen)

assteen

1600-1900

$\theta$ halssteen

$\Delta$ marbel(steen)

assteen
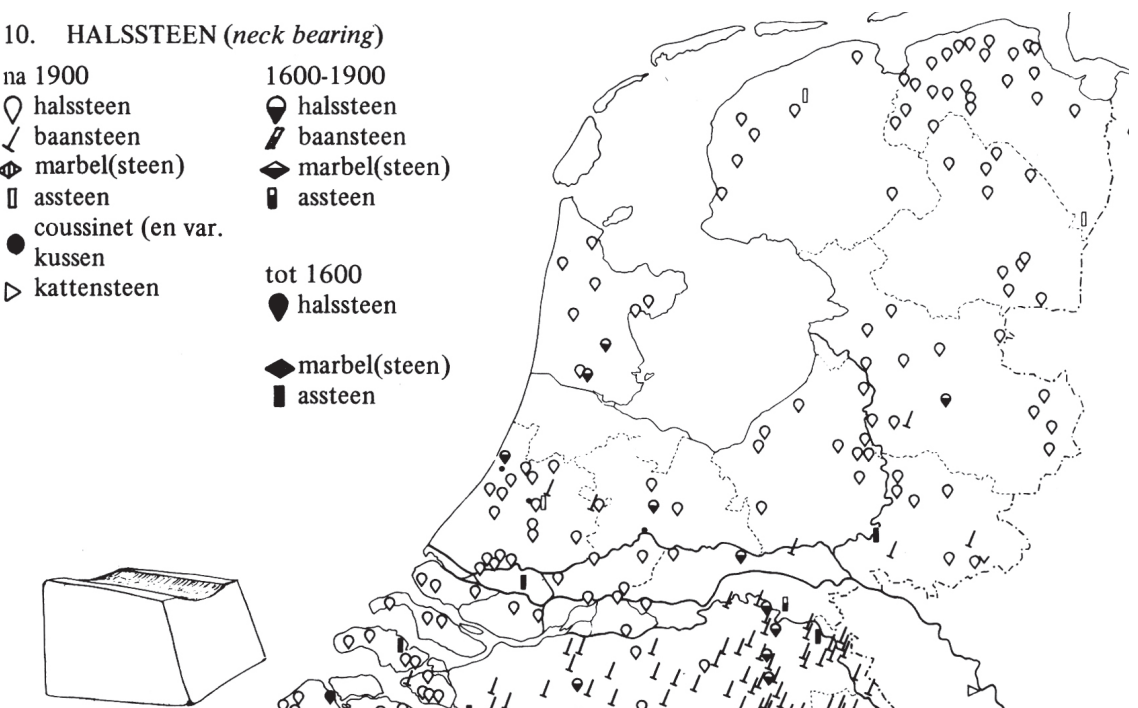

Q 00090
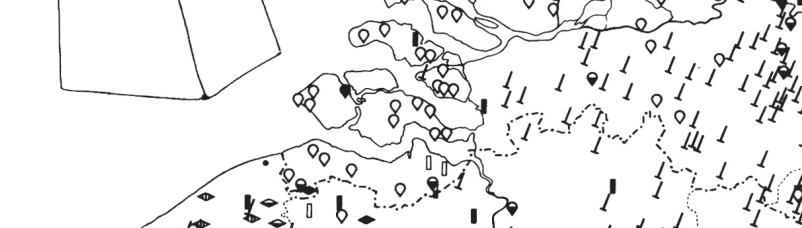

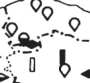
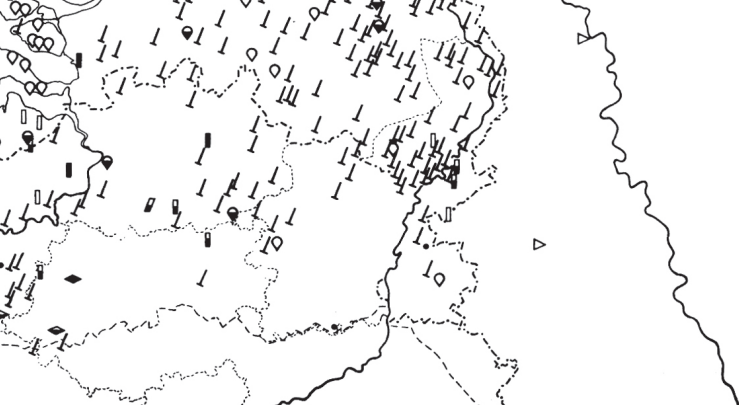

Kaart 7 (halssteen)

zelfs nog specifieker aangeven waar de as ondersteund wordt.

Deze steen staat op een balk die de windpeluw of windpulm heet, of assebalk, banebalk, kussen, marbelbalk of steenbalk. Peuluw, peluw en pulm zijn vroege ontleningen uit het Latijnse pulvinus. Je herkent er het Engelse woord pillow nog in. Peuluw komt in onze taal in verschillende vormen voor, waarvan peuluw en het thans als beschaafd geldende peluw de meest gewone zijn, maar ook de verkorte vorm peul(e) is vrij algemeen. Andere vervormingen zijn peuling, peulem en pulm. Het element windin deze samenstelling bespraken we hoger al. De windpulm is immers de horizontale balk in de zijde van de roeden, de windweeg dus. Dat deze balk ook assebalk, banebalk, marbelbalk en steenbalk heet, is vrij eenvoudig uit te leggen: de balk draagt de as, de baan, de marbel of de steen. Kussen is vergelijkbaar 
met peuluw, dat ongeveer dezelfde betekenis heeft.

\section{Het aswiel}

Rond de as zit een kamwiel dat de beweging van de as via een ander wiel (een wiel met staven) moet doorgeven aan de steen. Rond dit grote aswiel zit de rem, die in de molenterminologie meestal vang genoemd wordt (zie paragraaf 6). Dit wiel moet de horizontaal draaiende beweging omzetten in een verticaal draaiende beweging. Het is het grootste wiel in de molen, soms wel met een doorsnede van drie meter. Het aswiel bestond uit kruisarmen, plooien en een velg waarin de kammen gestoken waren. Rond de velg van dit wiel gaat de vang, de rem.

De namen voor het aswiel zijn heel doorzichtig: samenstellingen met in het westen overal wiel, in het oosten rad als tweede element. Het eerste deel van de samenstelling kan as- zijn: het wiel dat op de as is bevestigd. Groot wiel werd gebruikt om dit wiel te onderscheiden van andere kleinere wielen in de molen. Kamwiel verwijst naar de kammen die dit wiel heeft. Het geheel van die kammen die op de velg waren ingeplant vormen een kroon, vandaar kroonwiel. Bovenwiel verwijst naar de plaats van het wiel in de windmolen en vangwiel naar de rem die rond dit grote wiel ligt.

\section{De vang}

De vang of de rem die gebruikt wordt om de draaiende roeden van de windmolen tot stilstand te brengen is een houten hoepel (meestal uit vier of vijf segmenten, soms uit één stuk) met een ijzeren band errond. Deze rem ligt rond het grote wiel en werkt zoals een trommelrem. Het ene uiteinde van de hoepel ligt vast, terwijl aan het andere einde de zware vangbalk hangt, die als hij uit de ruststand getild wordt door zijn gewicht de vang nauwer om het draaiende kamwiel trekt totdat de molen stilstaat. Er zijn verschillen tussen de Hollandse vang en de Vlaamse, en ook de bediening van de vang kan verschillen. Er zijn vier benamingen in ons taalgebied: vang, praam, prang en frein, waarvan vang de meest verspreide is. Praam komt voor in Limburg, prang in Brabant. Frein komt slechts zelden voor. Stroop vermeldt dat 


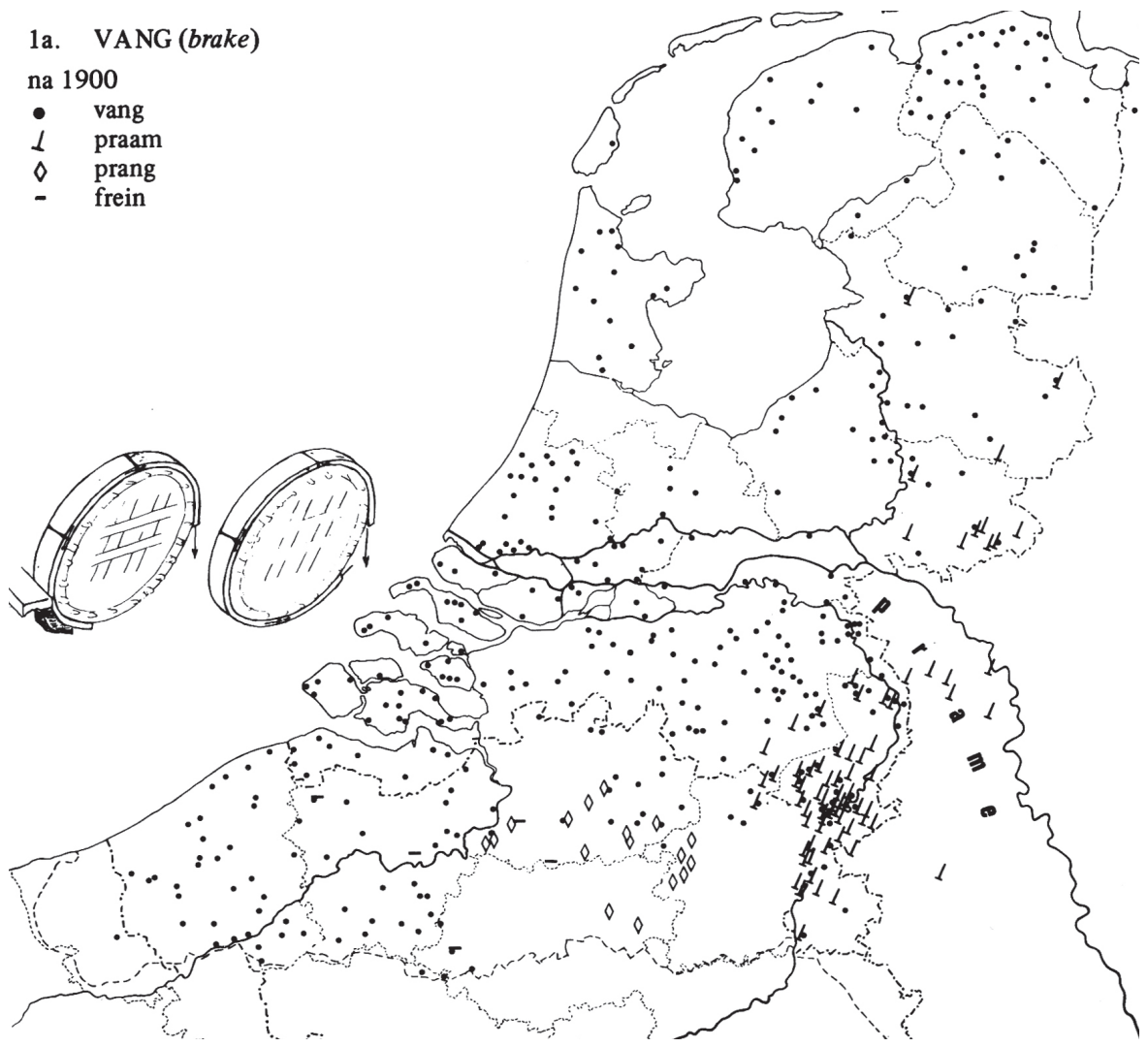

Kaart 8: vang (Stroop : 20)

er in oorsprong een woord ghevange bestond, maar dat de ge- daarvan is weggevallen. Het woord zou afgeleid zijn van het werkwoord gevangen, waarin het voorvoegsel de voltooide handeling uitdrukt en hier de betekenis heeft van 'door grijpen of vatten in zijn macht brengen'. Ge is later - toen het functieloos was geworden - afgevallen. En zo is vang ontstaan. (Stroop : 17-25)

Praam en prang hebben iets gemeenschappelijks in hun betekenis en etymologie. Ze kunnen beide herleid worden tot een werkwoord dat 'drukken' betekent en frein is het Franse woord dat afgeleid is van het Latijn frenum dat 'teugel' betekent.

\section{De lantaarn}

Het kamwiel waarop de vang zit, draait in een wiel met spillen, een schijfloop. Dit onderdeel kent heel wat benamingen in ons 
taalgebied: lantaarn, schijfloop, rondsel, enz. Het is een spillenof stavenrad dat bestaat uit twee schijven van olmenhout met daartussen twaalf of veertien houten staven. Door dit rondsel gaat een grote spil die de stenen aandrijft. Dit wiel is een wiel met spillen omdat de stenen een beetje moeten kunnen bewegen naar boven, en dat kan omdat een toestel, de licht, ervoor zorgt dat de bovenste steen wat hoger of lager kan draaien. Doordat de steen hoger en lager kan, moet ook de spil hoger en lager geplaatst kunnen worden. Dat betekent dat de lantaarn of het rondsel ook mee naar boven en beneden beweegt, maar toch moet zorgen voor een continue beweging met het kamwiel. En dat kan alleen als de kammen tussen de staven kunnen blijven grijpen, ook al zakt of stijgt de spil een beetje.

Van zeker één van de benamingen weten we dat die te maken heeft met de opkomst en de verspreiding van de watermolen, $\mathrm{nl}$.

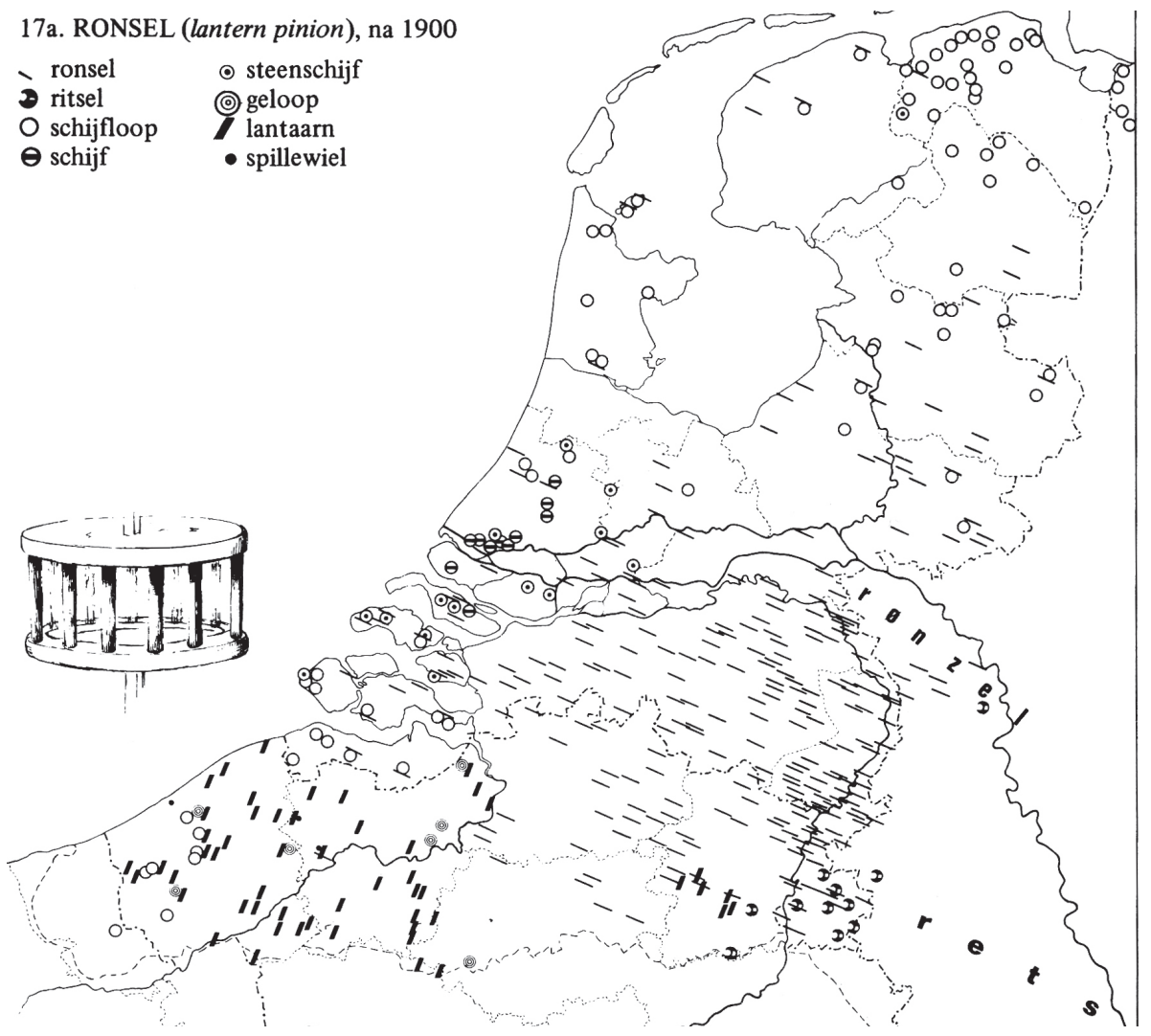


het Romaanse lantaarn. Het woord hangt samen met de vorm van dit onderdeel. De oudste lantaarn had immers een ronde vorm en bestond ook uit twee schijven met daartussen een aantal spijlen. Die benaming en vorm vindt men nog terug in de bouwkunde. Schijfloop en spillegeloop zijn beide afgeleid van het werkwoord lopen, waarmee hier de beweging van dit onderdeel wordt bedoeld. Schijf en spillen verwijzen naar de vorm van dit onderdeel. De term geloop kan een simplificatie zijn van de vorige benamingen, maar kan ook de oudere benaming zijn, waarbij de vorige benamingen dan specificerende benamingen geworden zijn. Spillewiel verwijst weer naar de spillen en klein wiel moet het hebben van de tegenstelling met het grote aswiel.

De andere frequent voorkomende benamingen zijn rondsel, ritsel, rutsel enz. De etymologie is niet zo duidelijk. Stroop zegt het volgende: "hoewel rondsel en ritsel op het eerste gezicht de indruk wekken verwante termen te zijn, beide beginnen met een $r$ en zijn met een verwant suffix gevormd en doen vermoeden dat ze alleen door een eventueel assismilatieproces van elkaar zijn gaan verschillen, toch moeten we ze als aparte benamingen beschouwen". (Stroop: 185)

Ronsel bijvoorbeeld kan samenhangen met het adjectief rond. Sommigen suggereren dat het een verkleinvorm is van rons. Stroop denkt echter aan een afleiding van een werkwoord met

-sel. Hij denkt aan het werkwoord rinnen/rennen (denk aan renne voor 'schommel'). Er zijn echter ook wel wat bezwaren.

176 Het wijst - als we deze etymologie aanvaarden - op beweging. Dat geldt ook voor ritsel. Rutsel zou dan een rondingsproduct kunnen zijn. Er komen ook geassimileerde vormen voor zoals russel en rossel.

\section{De grote spil}

Het rondsel zit op de grote spil, de staande as die de steen in beweging zet. De grote spil moet de beweging van het aswiel immers doorgeven aan de rijn, een ijzer in de molensteen, en zo aan de bovenste molensteen. Zowel de watermolen als de windmolen hebben een dergelijke spil, maar de plaats is in beide molens verschillend. Ik beperk me tot de windmolen, waar deze spil zich steeds boven de stenen bevindt. Hij draait bovenaan in 
12a. GROTE SPIL (quant), na 1900

/ $\begin{array}{lll}\text { spil } & \text { I staakijzer } \\ \text { klauwspil } & \text { Y klauwijzer }\end{array}$

$>$ steenspil d vorkijzer

\% maalspil O molenijzer

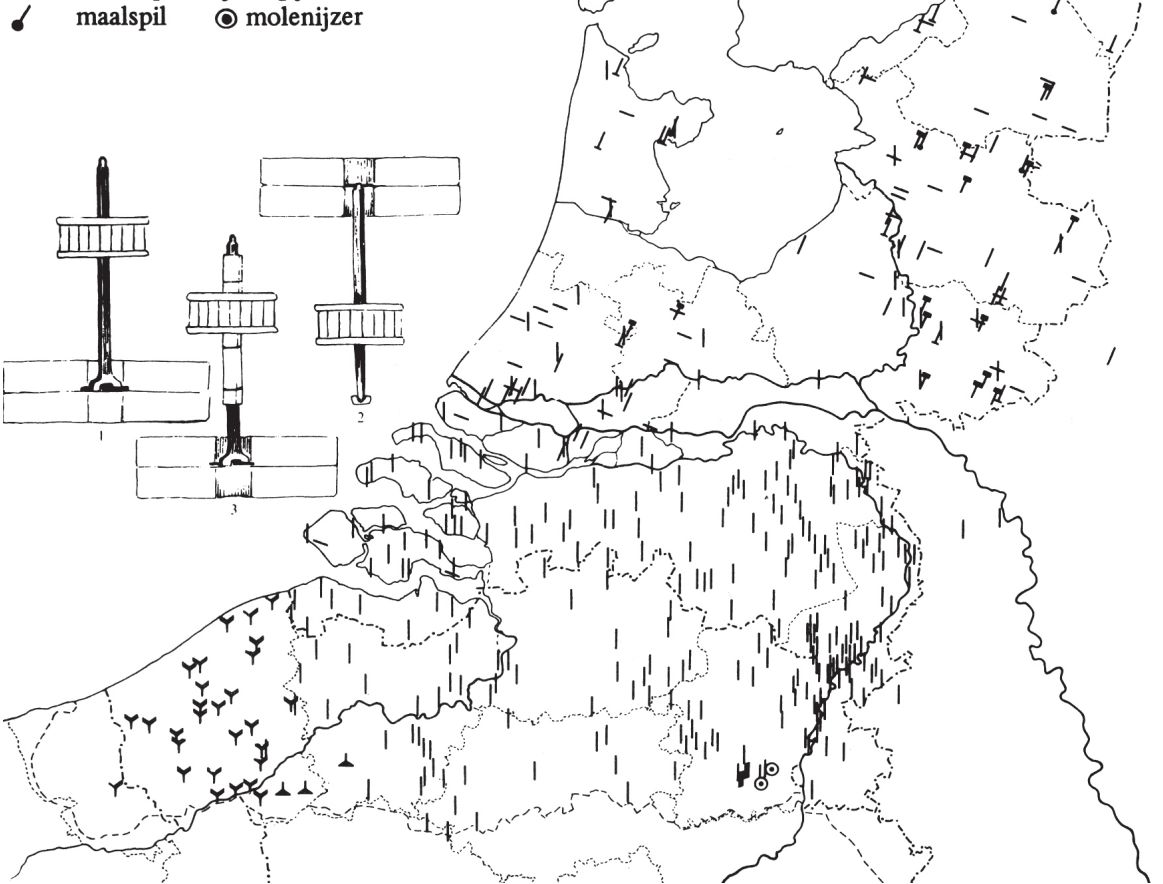

kaart 10: de grote spil of het klauwijzer (Stroop : 128)

een balk en grijpt met een klauwvormig ondereind over de rijn. De rijn zelf rust op de kleine spil (zie tekening 2).

De benamingen voor de grote spil zijn gemakkelijk, ze refereren allemaal aan het uiterlijk van de spil. De meest algemene benaming is spil. Steen- en maalspil verwijzen naar de functie (maalspil is de spil die ervoor zorgt dat het graan gemalen wordt, brengt de stenen aan het malen en steenspil verwijst naar wat aangedreven wordt, de stenen waarmee men maalt). De spil wordt ook bovenspil genoemd omdat hij in een windmolen boven de stenen staat (en vormt daardoor een tegenstelling met het ijzer onder de steen dat onderijzer genoemd kan worden). Molenijzer komt ook voor. Deze benaming was vroeger de naam voor de rijn, maar toen die een andere naam kreeg is het molenijzer overgegaan op dit onderdeel. Langijzer verwijst naar de lengte van deze spil. Dat geldt ook voor staakijzer; een staak moet altijd een zekere lengte hebben, denk aan de benaming staak voor 
de standerd van de houten molen. Vork- en klauwijzer verwijzen naar de klauwvormige voet.

Op kaart 10 van het Nederlandse taalgebied kunnen we twee gebieden onderscheiden, nl. een met ijzer en een met spil, de grens loopt ongeveer gelijk met de grote rivieren.

\section{De kleine spil}

Er is ook een kleine spil in de molen. Die zit gedeeltelijk in en onder de liggende molenstenen. Hierop rust de rijn, die precies over de nok van de kleine spil past. Onder die nok is de kleine spil rond en dikker dan het onderste gedeelte (zie tekening 2). Dat dikke gedeelte draait in de bus in de onderste molensteen, de ligger. De spil moet precies in die bus passen zodat geen meel verloren gaat. De spil eindigt in een rond uiteinde dat in een ijzeren of stalen pot draait, de spoorpot. Die pot is gemonteerd op een balk die omhoog en omlaag bewogen kan worden, om de afstand tussen de stenen te regelen (een onderdeel van de licht). De benamingen zijn soms te verklaren uit de aanwezigheid van de grote spil, zoals bijvoorbeeld kleine spil, klein (molen)ijzer, onderspil, onderijzer. De andere benamingen verwijzen naar de vorm van de spil en dan meestal naar het dikkere gedeelte dat in de bus draait. Zo heb je hals, peer, peerijzer, perestaf. Ook borstspil en bolspil houden verband met die verdikking.

\section{10. De rijn}

De rijn zelf is een speciaal ijzer dat zich in de bovenste steen, de loper bevindt. Tegenwoordig is dat een kruisvormige rijn, maar vroeger was er ook een model met twee takken. De rijn met de dubbele zwaluwstaart is lang het voornaamste type gebleven. Molenijzer is een merkwaardige benaming, omdat het woord nu niet meer in de terminologie van de molenaar voorkomt, maar wel een gangbare benaming is in heraldische kringen. De naam molenijzer voor de rijn hangt samen met het feit dat er nauwelijks ijzer aanwezig is in de molen. In oude rekeningen wordt gesproken van vier grote ijzers, en dat zijn de vier die op tekening 2 worden getoond.

De oudste benaming voor de rijn is het Latijnse anaticula, letterlijk 
13a. KLEINE SPIL (stone spindle), na 1900

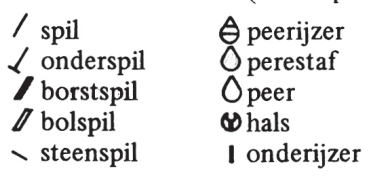

(n) 1900

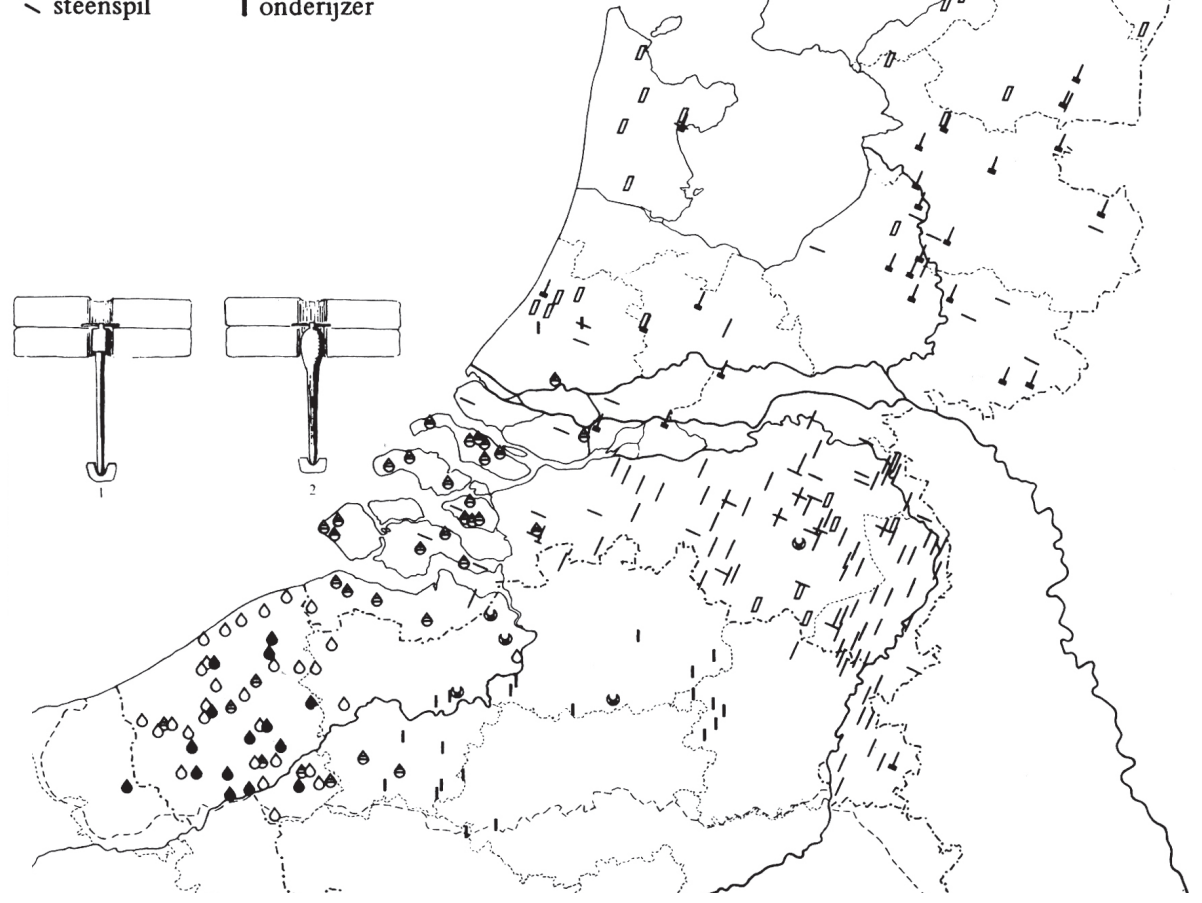

Kaart 11: de kleine spil (Stroop : 144)

'eendje' dat als molenterm nu in alle Romaanstalige landen van Europa aangetroffen wordt. Een Nederlandse benaming die met het uiterlijk te maken heeft, is desser. Het is hetzelfde woord als dessel in de betekenis 'houweel'. Die naamsovereenkomst is te verklaren op basis van de uiterlijke overeenkomsten tussen zo'n houweel met steel en de rijn met de kleine spil of onderijzer.

De etymologie van de Nederlandse benaming rijn is moeilijk. Een van de mogelijke etymologieën die Stroop (108) geeft, is dat het woord samenhangt met het werkwoord rinnen (cfr. hoger), maar de kans is wellicht klein omdat de meeste benamingen voor de rijn gebaseerd zijn op de uiterlijke kenmerken van dit onderdeel. Stroop vermoedt dat de naam te maken heeft met het Latijnse rana dat 'kikvors' betekent en dus gebaseerd is op vergelijking met dit dier (Stroop : 108). 
11a. RIJN (rynd)

na 1900

rijn

(11) desser

$\theta$ (steen)kruis

molenijzer

$\varnothing$ brug

G how

Kaart 12: de rijn (Stroop : 112)

\section{Steen en graanbak}

Met de spillen en de rijn zijn we bij de twee maalstenen, de loper en de ligger (de ene loopt, de andere ligt stil) terechtgekomen. Ze zitten in een steenkuip, met daarop een bak, het kaar, in de vorm van een afgeknotte piramide, die zich boven de bovenste molensteen bevindt. (zie tekening 1) Het graan wordt in deze trechter gestort en komt eerst in het schoe, vervolgens in het kropgat van de molensteen terecht. De bak rust op twee balkjes, kaarbomen, die zelf weer dragen op het deksel van de steenkuip. Het schoe is een klein schoenvormig bakje dat, doordat het voortdurend tegen de vierkante draaiende grote spil slaat, in een 


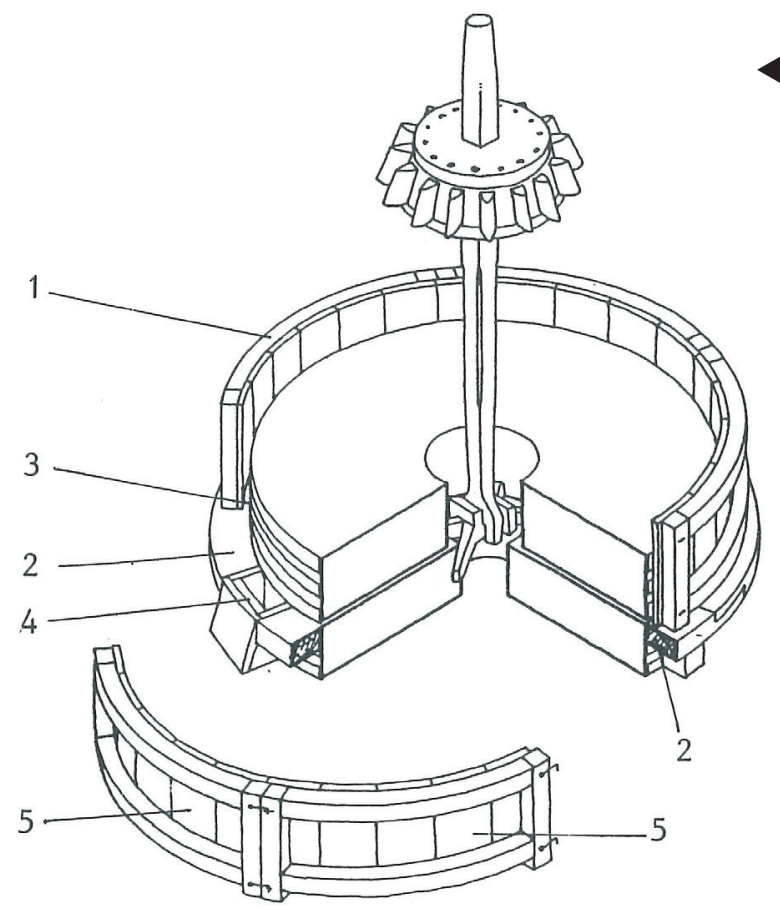

Tekening 1 : steenkuip met de maalstenen en de grote spil (Woordenboek van de Vlaamse Dialecten)

1 steenkuip, 2 ringhout,

3 ruimte tussen steen en kuip, 4, meelgat, 5 kuipstuk.

Tekening 2 : viertakrijn met bovenaan de grote spil, onderaan de kleine spil en spoorpot (Woordenboek van de Vlaamse Dialecten)
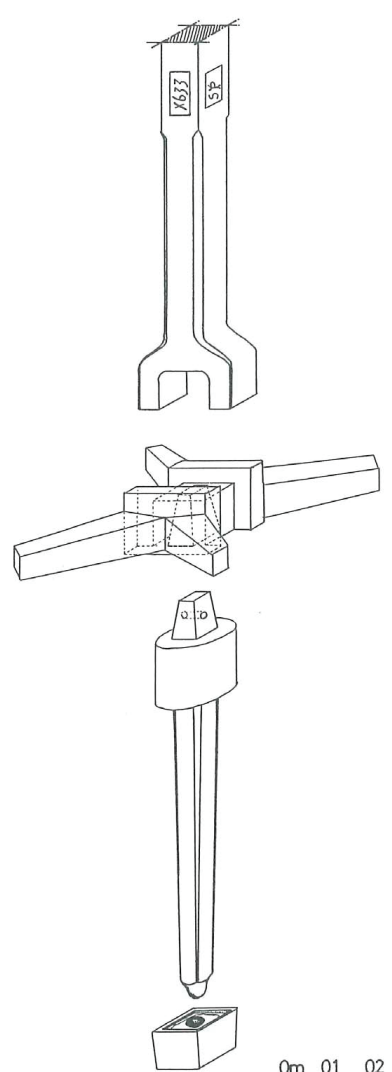
constante schuddende beweging is. Het graan loopt daardoor in regelmatige hoeveelheden in het kropgat van de molensteen. Graanbak is uiteraard de meest doorzichtige benaming: de bak waar men het graan in giet. Dergelijke constructies komen ook voor in oude rekeningen, het zijn samenstellingen met woorden die tot de algemene woordenschat behoren. Het gebruik van het adjectief grote zowel bij graanbak als bij bak dient als tegenstelling met het veel kleinere bakje, het schoe, onder aan de stenen.

Het woord kaar is dan weer een simplex, maar het is een woord dat volgens Stroop ook elders in Europa voorkomt. Het is de naam voor allerlei soorten vaatwerk van lijkkist tot braadpan. De etymologen zijn het erover eens dat het woord kaar een specifiek Germaans woord is. Bij ons is het in gebruik voor een vismand en een bijenkorf. Dat geldt ook voor romp, dat als bijenkort bekend is in onder andere Sleeswijk-Holstein en Mecklenburg. Deze beide woorden sluiten daarmee aan bij een reeks Zweedse namen voor het kaar, die ook gebruikt worden voor vaten van allerlei vlechtwerk zoals de bijenkorf en de viskorf. Er zijn etymologen die romp en kaar proberen te herleiden tot de grondbetekenis 'uitgeholde boomstam' en dat is eigenlijk wel plausibel. Om echter tot de molenbetekenis te komen, dient na de grondbetekenis een algemene betekenis 'vaatwerk in de vorm van een holle boomstam' te worden toegevoegd. Dan is het ook niet nodig aan te nemen dat er bij het vissen werkelijk holle boomstammen zijn gebruikt.

182 Tremel is de enige Romaanse benaming onder de benamingen voor het kaar. De vorm treme die voorkomt in het ouder Nederlands is te herleiden tot het Latijnse trimodia, oorspronkelijk de naam voor een vat met een inhoud van drie schepel (Stroop : 205-215).

Enkele onderdelen zoals de licht (het systeem om de stenen van elkaar te lichten) en het luiwerk (het systeem om zakken op te trekken), de standerd en de teerlingen van de standerdmolen, de spruiten of schoren van de stenen molen bleven onbesproken. Toch willen we graag op basis van de besproken gegevens tot een soort samenvatting komen, die vooral gebaseerd is op wat Stroop in zijn onderzoek heeft onderzocht (Stroop : 219-230. 


\section{Besluit: benoemingsmotieven in de molenterminologie en ontstaan van molentermen}

Voor de naamgeving in de molenterminologie worden diverse benoemingsmotieven gebruikt. Uiteraard zijn deze motieven universeler toepasbaar dan enkel op de molentaal. Een beroepstaal moet zich immers behelpen met zaken uit de algemene woordenschat van de overkoepelende taal in die regio of dat land.

Een algemene manier om dingen te benoemen is gebruikmaken van metaforen: men benoemt een voorwerp op grond van zijn uiterlijke gelijkenis met een andere zaak. In de molenaarsterminologie hebben we bijvoorbeeld klauwijzer, vorkijzer, peerijzer en lantaarn. Overeenkomst met lichaamsdelen is ook bij de molen een vrij vaak voorkomend motief: pestel, borst, hals. Dierlijke metaforiek is aanwezig in rijn, maar ook in kikkers of puiten - dat zijn de haken waarachter de zeilen worden vastgemaakt.

Een betrekkelijk weinig voorkomend motief is dat van het materiaal waarvan een onderdeel gemaakt is, maar dat is ook begrijpelijk want bijna alle molenonderdelen zijn van hout; we kennen wel de namen voor de vier grote ijzers: staakijzer, klauwijzer, molenijzer, groot ijzer, klein ijzer, peerijzer en houten molen en stenen molen. Enkele namen zijn afgeleid van werkwoorden: rutsel, ronsel, schijfloop, spillegeloop, vang, praam, prang, ook loper en ligger. De molenaarsterminologie kent naast directe ontleningen een aantal gevallen van leenvertaling. Dat is het vertalen van een woord uit een bepaald woordveld van een ander taalsysteem. Bij de vang waren dat prang en praam die opgevat kunnen worden als leenvertaling van pass. Ook romp 'kaar' zou als zodanig kunnen worden beschouwd. Het verschijnsel heeft te maken met de omstandigheid dat het steeds namen betreft voor begrippen die ook ontleend worden. Nog duidelijker blijkt dat bij het grote aantal ontleningen dat in de molenaarsterminologie voorkomt. Echte ontleningen zijn bijvoorbeeld oorspronkelijk Romaanse woorden als pestel, rijn, lantaarn en tremel. Evengoed zou je bij een aantal Germaanse namen van ontleningen kunnen spreken, maar het is moeilijk om aan te tonen of een woord echt is overgenomen of al in het eigen taalsysteem aanwezig was en 
een betekenisuitbreiding onderging.

Bij de naamgeving neemt men ook een zeker streven naar gemeenschappelijke kenmerken waar. Zo zijn windluiken en windborden in veel plaatsen zo genoemd naar de windzijde. Waar die stormeind heet, komen voor de hoger genoemde onderdelen namen voor als stormluiken en stormborden. Waar het windweeg is, tekenen we windborden of windluiken op.

Een ander vaak voorkomend motief is werken met tegenstellingen zoals in groot en klein ijzer, bovenwiel en onderwiel, bovenspil en onderspil.

Er zijn ook veel samengestelde benamingen in de molenterminologie, die te herleiden zijn tot een substantief met een beperkende nabepaling. In een aantal gevallen gingen deze constructies echt vooraf aan de huidige namen. Dat kunnen we uit oude rekeningen opmaken. Voorbeelden zijn: bak daarmen tcoren in gheit $\rightarrow$ korenbak; daar tgroot ijzer in loopt $\rightarrow$ ijzerbalk; cupe die om den steen staan $\rightarrow$ steenkuip. Woorden zoals assteen, kamwiel, korenwiel, vangwiel, windzijde en standerdmolen zijn eveneens voorbeelden.

Weinig molentermen zijn ontstaan in de Nederlanden. Het aantal heteroniemen bij verreweg de meeste onderdelen is opvallend klein. Dit hangt ongetwijfeld samen met het beroep van de molenaar. In kleine plaatsen was zelden meer dan een molenaar werkzaam, bovendien werd het werk gedaan buiten de woonkernen. Een molenaar bevond zich dus in twee

184 opzichten in een geïsoleerde positie. Hij woonde en werkte zonder onmiddellijke buren, en had vrijwel geen contact had met collega's van elders. Als er al contact was, dan ging dat via de molenbouwer of molenhersteller. Veranderingen in de molenaarsterminologie gaan dan ook bijna altijd gepaard met technische veranderingen die van elders worden overgenomen.

Jan Stroop heeft met zijn onderzoek vooral willen aantonen dat er verschillende molengolven zijn geweest, die hun invloed hebben gehad op de taal van de molenaars. Stroop ziet een aantal vernieuwingen in de woordenschat opduiken met de opkomst van de Hollandse of stenen molen, sinds 1600 . Vernieuwingen die hiermee te maken hebben zijn de namen voor de schoren of spruiten (die we in dit artikel niet hebben besproken) en de 
windborden. Naamsveranderingen die door de invoering van dit type gebeurd zijn, zijn de namen voor het aswiel. Dat aswiel kreeg in de Hollandse molen de naam bovenwiel, omdat er twee grote wielen waren in een stenen molen. Er zijn ook oude benamingen die een nieuwe impuls krijgen bij het invoeren van dit nieuwe type. Dat geldt bijvoorbeeld voor de vang. Op oudere kaarten komt vang nooit voor in het oostelijke gedeelte, op nieuwere wel. De verandering valt zo precies samen met de opkomst van de Hollandse molen dat het niet moeilijk is er verband tussen te zien. Ook op een meer indirecte manier heeft de opkomst van de stenen molen invloed gehad op de ontwikkeling van de terminologie, bijvoorbeeld standerdmolen. Voor het nieuwe type er was, heette een houten molen gewoon windmolen.

De Brabants-Antwerpse regio vertoont eigen kenmerken. Zo is het ontstaan en de opkomst van staakijzer een AntwerpsBrabantse aangelegenheid, evenals die van hals voor kleine spil. Baan en baansteen vallen eveneens onder deze groep, ook al komen ze beide ook wel in Limburg en Vlaanderen voor en zijn ze opvallend jonger dan staakijzer en hals. Het lijkt erop dat Brabant in de ruimste zin maar toch in het bijzonder in het zuiden door de eeuwen heen een terminologisch eiland geweest is dat zijn termen ook naar omringende gebieden heeft uitgestraald.

Ook Vlaanderen, en meer specifiek West-Vlaanderen vertoont duidelijk eigen trekken. Vlaamse voorbeelden zijn klauwijzer en peerijzer. Een opmerkelijke jonge verandering is lantaarn, en ook graanbak en korenbak. Beide ontwikkelingen tonen aan dat Vlaanderen als windmolengebied lang een grote betekenis heeft gehad. Dit zijn vrij recente veranderingen, maar de meest typerende bestanddelen van de Vlaamse terminologie stammen nog uit de eerste tijd van de windmolen. Het zijn benamingen die ten tijde van de eerste windmolens vanaf ongeveer de $13^{\text {de }}$ eeuw in Vlaanderen zelf ontstaan zijn of eventueel in vertaling ontleend werden aan de naamgeving in Noordwest-Frankrijk. Ze hebben dan ook alle betrekking op de houten standerdmolen. Zo kennen we bijvoorbeeld staken, een voortzetting van atak dat in Noordwest-Frankrijk nog altijd gebruikt wordt. Ook pestel is hiervan een voorbeeld. Ook al is het woord etymologisch zo Romaans als maar kan zijn, een variant in Frankrijk is niet aanwijsbaar. Een ander woord dat het niet ver gebracht heeft, is 
windweeg, waarvan het gebied in grote trekken overeenkomt met het gebied van pestel en stake. Het grote belang van Vlaanderen als molenland blijkt het duidelijkst bij benamingen die niet tot dat gebied beperkt gebleven zijn, maar die zich na hun ontstaan of ontlening in Vlaanderen over het Nederlandse taalgebied verspreid hebben. De expansie van die benamingen illustreert hoe de oude standerdmolen vanuit Noordwest-Frankrijk via Vlaanderen en de Nederlanden is binnengedrongen. Een goed voorbeeld is de schijfloop of lantaarn. De tijds- en ruimteaspecten van de verspreiding daarvan vormen een weerspiegeling van wat met de windmolen zelf gebeurd is. Dat geldt ook voor rijn en vang: deze benamingen komen al vroeg voor in het zuidwestelijke deel, maar rijn en vang zijn benamingen van onderdelen die in technisch opzicht verschillen van soortgelijke onderdelen elders. Deze gebieden zeggen dus weinig of niets over de zuidwestelijke expansie van de windmolen als zodanig. Opvallend is ook nog dat het gaat om een omsingelende expansierichting: langs de kust, dan naar Oost-Nederland, en het middendeel niet.

Het verhaal van de taalgeografie loopt tot nog toe redelijk parallel met wat geschiedkundigen vertellen maar er moet ook nog een tweede verspreidingshaard geweest zijn. Stroop noemt dit de Rijnlandse expansie. Voorbeelden noemt hij praam, prang en pars, ook stander en borsten. Stroop besluit dat deze Rijnlandse expansie er moet geweest zijn rond dezelfde periode als in het zuidwesten, rond het einde van de $13^{\text {de }}$ eeuw. De oostelijke

186 expansie is dus ongeveer gelijktijdig met de zuidwestelijke verlopen. 


\section{NOTEN}

1. Dit artikel is gebaseerd op een lezing die werd gehouden op een studiedag over "vakwoordenschat en arbeidersdialecten" op 19 december 2008. Deze studiedag wordt georganiseerd door VIAT vzw en O.F.O.B.I.E (Oost-Vlaamse Federatie voor Oudheidkundig Bodemonderzoek en Industrieel Erfgoed), in samenwerking met VARIATIES vzw, Koepelorganisatie voor Dialecten en Oraal Erfgoed in Vlaanderen en Universiteit Gent, Vakgroep Nederlandse Taalkunde/Woordenboek van de Vlaamse dialecten.

2. Op de kaart die Stroop afdrukt is het Frans-Vlaamse woord buik niet geattesteerd. Het is wel te vinden in het Woordenboek van de Vlaamse Dialecten, dat pas na de studie van Stroop verscheen. Zie de woordkaart in die aflevering.

\section{GERAADPLEEGDE WERKEN}

L.-L. De Bo, Westvlaams Idioticon, Gent, 1873, 18922

P. de Kunder- J. de Hulster, Enige molen(aars)termen in ZeeuwsVlaanderen, scriptie M.O. - nederlands aan de Haagse leergangen, 1984.

V. De Tier, De terminologie van de windmolenaar in Oost-Vlaanderen, licentiaatsverhandeling, Gent, 1985.

V. De Tier en J. Van Keymeulen, Woordenboek van de Vlaamse Dialecten. Deel II Niet-agrarische vaktalen, aflevering 5. De Molenaar. Tongeren, 1990

J. Stroop, Molenaarstermen en molengeschiedenis. Amsterdam, 1977.

P.H. Vos en A. Weijnen, Woordenboek van de Brabantse Dialecten. Deel II Niet-agrarische vaktalen, aflevering 2. Brouwer en molenaar. Assen, 1983.

R. Vandenberghe, Woordenboek van de Vlaamse Dialecten. Deel II Niet-agrarische vaktalen, aflevering 7. De zeevisser. Tongeren, 2000. $\mathrm{H}$. van de Wijngaard en $\mathrm{H}$. Crompvoets, Woordenboek van de Limburgse Dialecten. Deel II Niet-agrarische vaktalen, aflevering 3. Molenaar. Assen/Maastricht, 1991. 